\title{
Submandibular Gland Adenoid Cystic Carcinoma
}

National Cancer Institute

\section{Source}

National Cancer Institute. Submandibular Gland Adenoid Cystic Carcinoma. NCI

Thesaurus. Code C5935.

An aggressive carcinoma that arises from the submandibular gland. It is characterized by the presence of malignant epithelial and myoepithelial cells forming cribriform, tubular, and solid patterns. It usually presents as a slow growing mass. Patients develop pain because of the tendency of these carcinomas to invade perineural tissues. 